\title{
Soil organic matter quality in three Mediterranean environments (a first barrier against desertification in Europe)
}

\author{
V. Aranda ${ }^{*}$, F. Comino ${ }^{2}$ \\ ${ }^{1}$ Geology Department, Soil Science Area, University of Jaén, Spain. ${ }^{2}$ Physical and Analytical Chemistry Department, University \\ of Jaén, Spain. *Corresponding author: varanda@ujaen.es
}

\begin{abstract}
The aim of this study was to establish the effect of parent material, climate conditions and vegetation type on soil organic matter (SOM) quality in different Mediterranean environments as an essential step for assessing soil stability; ecosystems in the first barrier against desertification in the western Mediterranean region. Thirty-six samples were taken from the organic-mineral horizon of unreclaimed soils with calcareous, acid metamorphic and calcareous/volcanic substratums; and from beneath three vegetation types (natural forests, reforested forests and scrublands) in areas of significant ecological value. The humus fractions and soil respiratory activity of bulk soil samples were studied, and some structural features of the humic acids extracted were characterized by elemental analysis and visible and infrared spectroscopies. Results indicate that SOM in the surface horizons of the calcareous and calcareous/volcanic areas showed higher biogeochemical transformation, where microbial synthesis in humic acids formation, including condensation mechanisms, prevails. In contrast, the acid metamorphic area showed the greatest differences, and would be considered more fragile in terms of organic matter stability to changes in the biogeochemical system. The results also indicate some differences due to the type of vegetation on soil humus chemistry. Under reforested forests of Pinus in an edaphic acid environment, humic acids showed a marked aliphatic character, displayed higher $2920 \mathrm{~cm}^{-1} \mathrm{IR}$ band, well defined typical lignin patterns, and higher $\mathrm{E}_{4} / \mathrm{E}_{6}$ ratio, i.e., accumulation of inherited macromolecular substances. The SOM beneath scrubland and natural Quercus forests may be said to be more decomposed (active breakdown of biomacromolecules) than beneath Pinus, humic acids exhibited higher aromaticity and were associated with accumulation of newly formed perylenequinonic chromophors of fungal origin, i.e., was at more advanced and complex stages of humification.
\end{abstract}

Keywords: Soil humic acids, humification mechanisms, reforested forests, Mediterranean mountains 


\section{Introduction}

Soils in the Mediterranean region are extremely vulnerable, especially those in high-mountain and semi-arid or arid areas. This is particularly important because one of the main environmental problems facing the regions bordering the Mediterranean sea, and large areas of the European Mediterranean region, is the threat of land degradation and progressive desertification (Rubio and Recatalá, 2006; Hill et al., 2008). Mediterranean mountain ecosystems, many of them well conserved, are of great value in slowing desertification because of the generalized presence in the region of intensively cultivated lands. Human pressure has also modified land use in mountain environments with different production systems and exploitation of resources for decades, resulting in unknown ecological effects.

Study of the nature of SOM, and their relationship with vegetation type and other environmental factors, is vitally important in areas with high risk of degradation and desertification, such as the Mediterranean region, where this information is of great importance for evaluating soil stability, and thus, the fragility of their ecosystems. Knowledge about SOM is essential to be able to assess the consequences of modifying some highly specific ecological and pedological conditions in the vulnerable ecosystems in the Mediterranean region, in a context where climatic conditions become more extreme.

Organic matter is essential in the stabilization of soil aggregates, water infiltration, conservation of biogeochemical nutrient cycles, and erosion control. The soil organic carbon pool is an important part of the global carbon pool and plays an essential role in global climate change and ecosystem stability (Li et al., 2013). The susceptibility of soils to erosion in Mediterranean mountainous areas largely depends on upper mineral soil horizon properties, which are controlled by or related to humus form development (Sevink et al., 1998). Low SOM concentrations in arid or semiarid environments can lead to progressive degradation of their quality and productivity (Caravaca et al., 2002). Soils having organic matter with higher humification degree are more stable and more resistant to the onset of degradation. Hence, because SOM quality is also of vital importance from the perspective of its environmental functions, as reported in several articles in the area under study (e.g., Aranda et al., 2011; Miralles et al., 2012), and coinciding with Almendros et al. (2005), the interest of assessing SOM quality rather than its total concentration must be underlined.

Some studies related to SOM quality have been done in the southernmost zone of Mediterranean Europe (Oyonarte et al., 1994; Delgado et al., 2007; Miralles et al., 2007; Miralles et al., 2012). However, some aspects as important as the effect of the parent material, climate conditions and vegetation, including intensive reforestation, have been poorly studied. According to Castro et al. (2004) and Ruiz-Sinoga et al. (2012), the development of suitable strategies for identifying those silvicultural and management practices in the Mediterranean basin remain a major issue. Additional information on general factors affecting soil $\mathrm{C}$ sequestration or stabilization in the area under study would be of great interest.

The protected natural areas in the south western-most part of the Mediterranean basin studied in this work have many natural environments containing native and managed soils. All of them provide Europe's first barrier against the advance of desertification from North Africa. In this context, the general aim of this work was to study the characteristics of organic matter and the prevailing humic substances formation processes in soils from three natural areas of high ecological value in severe risk of degradation. The primary goal was to analyse the influence of the parent material and vegetation type on the evolution and quality of the organic fraction in these fragile Mediterranean environments. The secondary goal was to verify the current influence of intensive reforestations with pine trees before becoming natural parks. 


\section{Materials and Methods}

\subsection{Site description and soil sampling}

The soil samples studied were taken from 36 uncultivated soils (Ah horizons) in three areas of high ecological value in SE Spain (Figure 1). The Sierra Nevada National Park, (SN): 12 soils over an acid metamorphic substratum, xeric soil moisture regime, and mesic soil temperature regime. The Cazorla-SeguraLas Villas Natural Park, (SC): 12 soils over a calcareous substratum, xeric soil moisture regime, and mesic soil temperature regime. And the Cabo de GataNíjar Natural Park, (CG): 12 soils over calcareous and volcanic substrata, arid soil moisture regime, and thermic soil temperature regime. The climate is typically Mediterranean in all three zones, with strong seasonal contrasts. Mean annual rainfall was $595 \mathrm{~mm}$ in $\mathrm{SN}, 866 \mathrm{~mm}$ in $\mathrm{SC}$ and $240 \mathrm{~mm}$ in CG. The mean annual temperatures were $9.8^{\circ} \mathrm{C}$ in $\mathrm{SN}, 11.1^{\circ} \mathrm{C}$ in $\mathrm{SC}$ and $17.8^{\circ} \mathrm{C}$ in $\mathrm{CG}$.

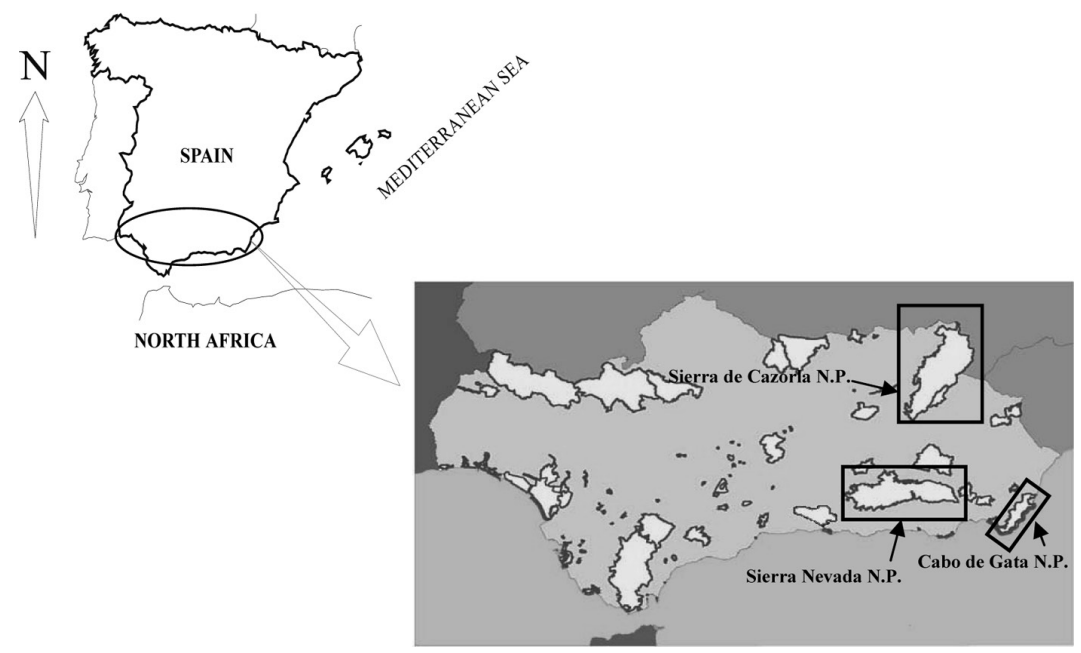

Figure 1. Distribution of protected natural areas in Andalusia (Southern Spain) and location of sampling areas: Sierra Nevada National Park (SN samples), Sierra de Cazorla Natural Park (SC samples) and Cabo de Gata Natural Park (CG samples).

The soils to be sampled within each sampling zone were chosen from three vegetation types: monospecific natural forests (B), about 50-60-year-old monospecific pine tree reforestations (R) and high-diversity scrublands (M). While this criterion was applied in $\mathrm{SC}$ and $\mathrm{SN}$, in CG, only soils from scrubland were sampled as there was no other type of vegetation. The most relevant field data are shown in Table 1. Soil profiles were sampled and described, taking well conserved plant communities (coverage of $75 \%$ or more) across each natural park as references. Five subsamples were taken from surface horizons distributed randomly in a $10 \mathrm{~m}^{2}$ area around the location of the profile described. These field samples were mixed to form a single composite or bulk sample, which were then analysed in the laboratory. The mean sampling thickness for the Ah horizons was $16 \mathrm{~cm}$ (SN samples), $20 \mathrm{~cm}$ (SC samples) and $22 \mathrm{~cm}$ (CG samples), respectively. 
Table 1. Climatic and field general data of the soils from Mediterranean ecosystems (SE Spain)

\begin{tabular}{|c|c|c|c|c|c|c|}
\hline Soil & $\begin{array}{l}\text { Altitude } \\
\text { (m a.s.l.) }\end{array}$ & $\begin{array}{l}\text { MAR } \\
(\mathbf{m m})\end{array}$ & $\begin{array}{c}\text { MAT } \\
\left({ }^{\circ} \mathrm{C}\right)\end{array}$ & Soil type * & Vegetation type & $\begin{array}{c}\text { Geological } \\
\text { substrate }\end{array}$ \\
\hline $\mathrm{SN}-1$ & 1800 & 603.3 & 9.6 & Typic Haploxeroll & Quercus forest (Quercus pyrenaica) & Schists \\
\hline $\mathrm{SN}-2$ & 1850 & 614.9 & 9.3 & Lithic Haploxerept & Pinus forest (Pinus sylvestris) & Schists \\
\hline SN-3 & 1500 & 533.5 & 11.5 & Typic Haploxerept & Quercus forest (Quercus pyrenaica) & Schists \\
\hline SN-4 & 2700 & 812.8 & 3.8 & Lithic Eutrocryept & $\begin{array}{c}\text { Scrubland (Genista versicolor, Juniperus } \\
\text { hemisphaerica) }\end{array}$ & Schists \\
\hline SN-5 & 1600 & 556.8 & 10.9 & Typic Dystroxerept & Scrubland (Ulex sp., Cistus sp.) & Schists \\
\hline SN-6 & 1500 & 533.5 & 11.5 & Typic Haploxerept & Quercus forest (Quercus rotundifolia) & Schists \\
\hline SN-7 & 1320 & 491.6 & 12.6 & Typic Haploxerept & Pinus forest (Pinus sylvestris) & Schists \\
\hline $\mathrm{SN}-8$ & 1800 & 603.3 & 9.6 & Lithic Dystroxerept & $\begin{array}{c}\text { Scrubland (Adenocarpus decorticans, Genista } \\
\text { sp.) }\end{array}$ & Schists \\
\hline SN-9 & 2000 & 649.9 & 8.3 & Typic Dystroxerept & Pinus forest (Pinus sylvestris) & Schists \\
\hline $\mathrm{SN}-10$ & 1650 & 568.4 & 10.5 & Typic Haploxerept & Pinus forest (Pinus sylvestris) & Schists \\
\hline SN-11 & 1820 & 608.0 & 9.5 & Typic Dystroxerept & $\begin{array}{c}\text { Scrubland (Genista versicolor, Adenocarpus } \\
\text { decorticans) }\end{array}$ & Schists \\
\hline $\mathrm{SN}-12$ & 1620 & 561.4 & 10.7 & Entic Ultic Haploxeroll & Quercus forest (Quercus rotundifolia) & Schists \\
\hline $\mathrm{SC}-1$ & 1100 & 970.6 & 12.6 & Lithic Xerorthent & Pinus forest (Pinus pinaster) & Limestones \\
\hline $\mathrm{SC}-2$ & 1400 & 1128.3 & 10.5 & Typic Haploxeroll & Quercus forest (Quercus faginea) & $\begin{array}{l}\text { Calcareous } \\
\text { sandstone }\end{array}$ \\
\hline $\mathrm{SC}-3$ & 1250 & 1049.5 & 11.5 & Lithic Ultic Haploxeroll & Quercus forest (Quercus rotundifolia) & Limestones \\
\hline SC-4 & 1650 & 1259.7 & 8.8 & Lithic Haploxerept & $\begin{array}{c}\text { Scrubland (Erinacea anthyllis, Crataegus } \\
\text { monogyna) }\end{array}$ & Limestones \\
\hline $\mathrm{SC}-5$ & 1500 & 1180.9 & 9.8 & Lithic Haploxeroll & $\begin{array}{c}\text { Scrubland (Ulex sp., Retama sphaerocarpa, } \\
\text { Thymus sp.) }\end{array}$ & $\begin{array}{l}\text { Calcareous } \\
\text { Schists }\end{array}$ \\
\hline SC-6 & 1150 & 996.9 & 12.2 & Typic Haploxerept & Pinus forest (Pinus pinaster) & Marls \\
\hline SC-7 & 700 & 760.5 & 15.4 & Typic Haploxerept & Pinus forest (Pinus pinaster) & Clays \\
\hline SC-8 & 1590 & 634.0 & 9.9 & Lithic Haploxerept & Quercus forest (Quercus rotundifolia) & Dolomites \\
\hline SC-9 & 1780 & 558.0 & 8.7 & Lithic Haploxeroll & $\begin{array}{c}\text { Scrubland (Erinacea anthyllis, Berberis } \\
\text { hispanica) }\end{array}$ & Limestones \\
\hline $\mathrm{SC}-10$ & 1550 & 756.0 & 10.1 & Typic Haploxeroll & Pinus forest (Pinus pinaster) & Dolomites \\
\hline $\mathrm{SC}-11$ & 1200 & 459.0 & 12.4 & Lithic Haploxerept & Scrubland (Juniperus thurifera, Ulex sp.) & $\begin{array}{c}\text { Limestones/ } \\
\text { dolomites }\end{array}$ \\
\hline $\mathrm{SC}-12$ & 1410 & 634.0 & 11.0 & Lithic Haploxeroll & Quercus forest (Quercus rotundifolia) & Limestones \\
\hline CG-1 & 150 & 189.0 & 18.8 & Lithic Xeric Haplocambid & Scrubland (Stipa tenacissima) & Andesite \\
\hline CG-2 & 100 & 252.0 & 18.8 & Lithic Haplocambid & $\begin{array}{l}\text { Scrubland (Periploca angustifolia, Maytenus } \\
\text { europaeus, Chamaerops humilis) }\end{array}$ & Andesite \\
\hline CG-3 & 60 & 189.0 & 18.8 & Lithic Haplocambid & $\begin{array}{c}\text { Scrubland (Chamaerops humilis, Rhammus } \\
\text { lycioides, Pistacia lentiscus) }\end{array}$ & Andesite \\
\hline CG-4 & 3 & 169.1 & 18.8 & Typic Torripsamment & $\begin{array}{l}\text { Scrubland (Ziziphus lotus, Withania } \\
\text { frutescens, Rhamnus lycioides) }\end{array}$ & Sand dune \\
\hline CG-5 & 40 & 252.0 & 18.8 & Lithic Torriorthent & Scrubland (Stipa tenacissima) & $\begin{array}{c}\text { Reef } \\
\text { limestone }\end{array}$ \\
\hline CG-6 & 135 & 290.0 & 18.6 & Xeric Haplocambid & $\begin{array}{c}\text { Scrubland (Ulex parviflorus, Rosmarinus } \\
\text { officinalis) }\end{array}$ & $\begin{array}{l}\text { Andesite/ } \\
\text { Dacite }\end{array}$ \\
\hline CG-7 & 250 & 271.6 & 16.8 & Lithic Torriorthent & Scrubland (Stipa tenacissima) & $\begin{array}{l}\text { Sandstone/ } \\
\text { Limestone }\end{array}$ \\
\hline CG-8 & 200 & 252.0 & 16.8 & Xeric Torriorthent & Scrubland (Anthylis cytisoides) & $\begin{array}{l}\text { Andesite/ } \\
\text { Dacite }\end{array}$ \\
\hline CG-9 & 170 & 252.0 & 16.8 & Lithic Haplocambid & Scrubland (Thymus sp., Helianthemun $s p$. ) & Dacite \\
\hline CG-10 & 20 & 252.0 & 16.8 & Xeric Torriorthent & Scrubland (Thymus sp., Helianthemun sp.) & Beach-rock \\
\hline CG-11 & 200 & 252.0 & 16.8 & Xeric Torriorthent & Scrubland (Stipa tenacissima) & Limestone \\
\hline CG-12 & 350 & 259.0 & 17.4 & Xeric Haplargid & $\begin{array}{c}\text { Scrubland (Chamaerops humilis, Rhammus } \\
\text { lycioides, Pistacia lentiscus) }\end{array}$ & $\begin{array}{c}\text { Metagranite/ } \\
\text { Gneiss }\end{array}$ \\
\hline
\end{tabular}

Sampling zone: Sierra Nevada National Park (SN); Sierra de Cazorla Natural Park (SC); Cabo de Gata Natural Park (CG); MAR: mean annual rainfall; MAT: mean annual temperature; *SSS, USDA, NRCS (2006). 


\subsection{Soil analyses}

All analytical data for the soil samples analysed refers to the fine-earth fraction $(<2 \mathrm{~mm})$. The procedures used for analysis are outlined by the American Society of Agronomy and Soil Science Society of America (Page et al., 1982; Klute, 1986): The organic carbon $(\mathrm{OC})$ content was determined by the Walkley-Black's method with dichromate oxidation. Total $\mathrm{N}$ was measured by the Kjeldhal's method. The $\mathrm{pH}(1: 2.5, \mathrm{w} / \mathrm{v})$ in distilled water was found by potentiometry. The exchangeable bases were extracted with ammonium acetate solution, buffered to $\mathrm{pH} 7$, and concentrations determined by atomic absorption spectrophotometry (AAS). The free iron oxides were extracted with citrate-dithionite using the Holmgren's method and determined by AAS. The clay particle-size was determined using the Robinson's pipette method after elimination of the organic matter with $\mathrm{H}_{2} \mathrm{O}_{2}$ and dispersion with Na-hexametaphosphate.

The 36 samples were subjected to various analyses to characterize the organic matter present. Fractionation of SOM was done following the IHSS procedure (Swift, 1996). Physical separation of the particulate soil fraction consisting of the not-yet decomposed organic remains (free organic matter) by flotation in $0.1 \mathrm{M} \mathrm{H}_{3} \mathrm{PO}_{4}$, followed by centrifugation and repeated washing with distilled water before the particulate fraction was dried. Total extractable carbon for humic and non-humic substances was extracted from soil by mechanically shaking the samples with a solution of $0.1 \mathrm{M} \mathrm{NaOH}$ and $\mathrm{Na}_{4} \mathrm{P}_{2} \mathrm{O}_{7}$ at $\mathrm{pH} 14$ for $24 \mathrm{~h}$ at $60^{\circ} \mathrm{C}(1: 10 \mathrm{w} / \mathrm{v})$. The extracts were centrifuged and filtered (Millipore $0.45 \mu \mathrm{m}$ ). Separation of the total extractable carbon fraction into humic acids (HA) and fulvic acids (FA) was done by precipitation with $\mathrm{H}_{2} \mathrm{SO}_{4}$ (1:1 by volume) and purification with polyvinylpolypyrrolidone to eliminate non-humic carbon, respectively. The FA fraction was considered the soluble carbon remaining from the humic extract; and the corresponding HA/FA ratio was found. To obtain the insoluble organic carbon (HUMIN), the residue was treated with $1 \% \mathrm{Na}_{2} \mathrm{~S}_{2} \mathrm{O}_{4}$ followed by $1 \mathrm{M}$
$\mathrm{HCl}-\mathrm{HF}(1: 1)$ at $60^{\circ} \mathrm{C}$, in order to remove free oxides and clay, respectively; next, extractable humin was isolated by extraction with $0.5 \mathrm{MNaOH}$, and any remaining carbon was considered non-extractable organic carbon (NEOC). The amounts of carbon in the above fractions were quantified by wet combustion (Page et al., 1982).

Mineral impurities of the HA were eliminated as follows: the remaining humic extract was precipitated with $\mathrm{HCl}$, de-ashed with $1 \mathrm{M} \mathrm{HCl}-\mathrm{HF}$, redissolved in $0.5 \mathrm{M} \mathrm{NaOH}$, and centrifuged at $43,500 \mathrm{xg}$; the dissolved salts were eliminated using cellophane bags by dialysis, and finally freeze-dried. Elemental composition of the HA (ash-free basis) was determined with a PerkinElmer $240 \mathrm{C}$ microanalyser, and the $\mathrm{H} / \mathrm{C}$ and $\mathrm{O} / \mathrm{C}$ atomic ratios were calculated. A Shimadzu UV-240 was used for the visible spectroscopy to find the $\mathrm{E}_{4} / \mathrm{E}_{6}$ ratio (absorbance to $465 \mathrm{~nm}$ and $665 \mathrm{~nm}$ of the visible spectra) and the derivatographic spectrometry (valleys near $620 \mathrm{~nm}, 570 \mathrm{~nm}$ and $528 \mathrm{~nm}$ ), both in $0.2 \mathrm{mg} \mathrm{C}$ $\mathrm{mL}^{-1}$ solutions of $\mathrm{HA}$ in $0.1 \mathrm{M} \mathrm{NaHCO}_{3}$ (Stevenson, 1994). Infrared (IR) spectra were obtained from $\mathrm{KBr}$ pellets with a $2 \mathrm{mg}$ sample, using a Shimadzu FTIR8400 PC Fourier-transform spectrophotometer. The spectra were subjected to a digital procedure for resolution enhancement based on the subtraction of the raw spectrum from a positive multiple of its second derivative (Rosenfeld and Kak, 1982). Peak intensities in the original spectra were also tabulated after dividing their absorption values by that corresponding to the band at $1620 \mathrm{~cm}^{-1}$ (generally assigned to aromatic skeletal vibrations), obtaining relative optical densities in the IR range (wavelength $\mathrm{cm}^{-1}$ ).

Finally, the in vitro respiratory activity of soils (soil C mineralization potential) was determined by estimating the $\mathrm{CO}_{2}$ released from soil samples moistened to $60 \%$ of their water holding capacity at $24 \pm 1^{\circ} \mathrm{C}$, measured periodically for a period of 40 days with a Carmhograph-12 (Wösthoff) gas analyser (Almendros et al., 2005); the results referred to total mineralisation coefficient, taking into account that each soil had a different organic matter content, and was defined as milligrams of carbon released per $100 \mathrm{~g}$ of soil carbon per day. 
Table 2. Analytical data of the Ah horizons of the soil studied

\begin{tabular}{|c|c|c|c|c|c|c|c|c|c|}
\hline & \multicolumn{3}{|c|}{$\mathrm{SN}(\mathrm{n}=12)$} & \multicolumn{3}{|c|}{$\mathrm{SC}(\mathrm{n}=12)$} & \multicolumn{3}{|c|}{$\mathrm{CG}(\mathrm{n}=12)$} \\
\hline & $\begin{array}{c}\text { Range } \\
\text { Mean (SD) }\end{array}$ & Skew & Kurtosis & $\begin{array}{c}\text { Range } \\
\text { Mean (SD) }\end{array}$ & Skew & Kurtosis & $\begin{array}{c}\text { Range } \\
\text { Mean (SD) }\end{array}$ & Skew & Kurtosis \\
\hline$\underset{\left(\mathrm{g} \mathrm{kg}^{-1}\right)}{\mathrm{OC}}$ & $\begin{array}{c}3.7-58.2 \\
26.3(15.42)\end{array}$ & 0.90 & 0.03 & $\begin{array}{c}8.4-63.4 \\
33.1(16.82)\end{array}$ & 0.81 & -0.08 & $\begin{array}{c}1.0-30.5 \\
17.8(8.52)\end{array}$ & -0.73 & -0.15 \\
\hline $\begin{array}{c}\mathrm{N} \\
\left(\mathrm{g} \mathrm{kg}^{-1}\right)\end{array}$ & $\begin{array}{c}0.8-4.5 \\
1.9(1.08)\end{array}$ & 1.73 & 1.06 & $\begin{array}{c}0.7-4.5 \\
2.5(1.11)\end{array}$ & 0.22 & -0.21 & $\begin{array}{c}0.3-2.6 \\
1.5(0.60)\end{array}$ & -0.17 & 0.50 \\
\hline $\mathrm{C} / \mathrm{N}$ & $\begin{array}{c}5-17 \\
13(3.12)\end{array}$ & -1.89 & 3.36 & $\begin{array}{c}10-20 \\
13(2.66)\end{array}$ & 1.73 & 2.80 & $\begin{array}{c}3-15 \\
11(3.17)\end{array}$ & -1.21 & 1.52 \\
\hline $\begin{array}{c}\mathrm{pH} \\
\left(\mathrm{H}_{2} \mathrm{O}\right)\end{array}$ & $\begin{array}{c}4.9-7.4 \\
6.3(0.63)\end{array}$ & -0.88 & 1.13 & $\begin{array}{c}5.6-8.1 \\
7.4(0.73)\end{array}$ & -1.50 & 1.53 & $\begin{array}{c}5.2-8.6 \\
7.7(0.84)\end{array}$ & -2.81 & 6.33 \\
\hline $\mathrm{Ca}^{2+}$ & $\begin{array}{l}0.75-18.20 \\
6.24(4.61)\end{array}$ & 1.69 & 2.64 & $\begin{array}{c}9.0-55.5 \\
31.69(15.19)\end{array}$ & -0.22 & -0.91 & $\begin{array}{c}6.75-45.75 \\
31.56(14.14)\end{array}$ & -0.83 & -0.43 \\
\hline $\mathrm{Mg}^{2+}$ & $\begin{array}{c}0.25-3.38 \\
1.44(0.88)\end{array}$ & 1.08 & 0.65 & $\begin{array}{c}0.87-8.37 \\
2.89(2.19)\end{array}$ & 1.70 & 1.97 & $\begin{array}{c}0.37-14.0 \\
4.87(3.87)\end{array}$ & 0.99 & 1.17 \\
\hline $\mathrm{K}^{+}$ & $\begin{array}{c}0.13-0.67 \\
0.31(0.16)\end{array}$ & 1.17 & 0.80 & $\begin{array}{c}0.16-1.53 \\
0.68(0.42)\end{array}$ & 0.68 & -0.29 & $\begin{array}{c}0.16-1.86 \\
0.91(0.58)\end{array}$ & 0.58 & -0.73 \\
\hline CEC & $\begin{array}{c}7.63-27.38 \\
14.92(5.72)\end{array}$ & 0.90 & 0.39 & $\begin{array}{l}17.19-42.44 \\
24.83(6.63)\end{array}$ & 1.84 & 3.04 & $\begin{array}{c}1.15-17.45 \\
10.19(4.22)\end{array}$ & -0.71 & 0.86 \\
\hline $\begin{array}{c}\text { Base } \\
\text { Saturation } \\
(\%)\end{array}$ & $\begin{array}{c}7.1-83.7 \\
53.9(22.54)\end{array}$ & -0.74 & 0.15 & $\begin{array}{c}62.2-100 \\
92.3(13.75)\end{array}$ & -1.75 & 1.27 & $\begin{array}{c}75.3-100 \\
97.9(7.14)\end{array}$ & -3.46 & 8.48 \\
\hline $\begin{array}{l}\text { Free Iron } \\
(\%)\end{array}$ & $\begin{array}{c}2.25-4.04 \\
3.09(0.68)\end{array}$ & -0.01 & -1.38 & $\begin{array}{c}0.84-4.91 \\
1.99(1.05)\end{array}$ & 2.10 & 4.04 & $\begin{array}{c}0.15-3.52 \\
1.26(1.01)\end{array}$ & 0.96 & 0.57 \\
\hline $\begin{array}{l}\text { Clay } \\
(\%)\end{array}$ & $\begin{array}{c}5.3-14.0 \\
10.3(3.04)\end{array}$ & 0.10 & -0.43 & $\begin{array}{c}12.5-51.9 \\
24.9(10.28)\end{array}$ & 1.60 & 2.84 & $\begin{array}{c}4.4-34.9 \\
13.0(8.94)\end{array}$ & 1.30 & 1.88 \\
\hline
\end{tabular}

Range (minimum-maximum), Mean value and SD (standard deviation). OC: total organic carbon; N: total nitrogen; Exchangeable bases $\left(\mathrm{Ca}^{2+}, \mathrm{Mg}^{2+}, \mathrm{K}^{+}\right)$and cation exchange capacity (CEC) in $\mathrm{cmol}_{\mathrm{c}} \mathrm{kg}^{-1} \cdot \mathrm{SN}$ : Sierra Nevada N.P.; SC: Sierra de Cazorla N.P.; CG: Cabo de Gata N.P.

\subsection{Statistical analysis}

The results were subjected to descriptive statistical analysis, analysis of variance (one-way ANOVA) to discriminate among the means by the Fisher's least significant difference (LSD) procedure, principal components analysis (PCA), and correlations between variables with the Pearson's correlation coefficient. Statgraphics Centurion XVI software was used (StatPoint Technologies, Inc.).

\section{Results and Discussion}

\subsection{Basic soil characteristics}

The characteristics of the topsoil samples analysed are shown in Table 2. In general, SN was characterised by a neutral to acid $\mathrm{pH}$, coarse textures and low level of nutrients. SC was characterized by neutral to basic $\mathrm{pH}$, a high level of nutrients and the exchange complex saturated with calcium. SC also had the highest organic carbon (probably related to a higher mean annual rainfall) and clay content, which would explain its higher cation exchange capacity. Finally, $\mathrm{CG}$ was characterized by a basic $\mathrm{pH}$ and a high level of nutrients.

As mentioned above, the results were grouped according to two basic criteria defined by the sampling zones, climatic and geochemical environments, and vegetation type. Thus it was possible to analyse and compare the influence of these factors on some properties related to SOM quality. 


\subsection{Influence of the sampling zone on soil organic matter quality}

The selected characteristics of the SOM, grouped by sampling zone (i.e., lithology and climate conditions), are shown in Table 3. In organic matter fractionation, a significantly higher content in free organic matter (FOM) fraction was observed in SN than in SC or CG. The difference in biogeochemical conditions in the basic medium from the acid medium seems to be responsible for the significantly lower FOM fraction in SC and CG than in SN. The low condensation of humic substances can be observed in the prevalence of fulvic acids over humic acids (mean HA/FA ratios, related to the aromaticity and polymerization degree of humic substances, were less than one), mainly in samples from SN and SC. The humus fractions of total extractable humin (HUMIN) and nonextractable organic carbon (NEOC) are noteworthy. The HUMIN fraction had the highest means in CG and SC, significantly different from the SN samples. This fraction is made up of insolubilized humic colloids in a mineral matrix forming highly stable compounds (Stevenson and Cole, 1999; Almendros el al., 2005) that would greatly stabilize the soil. The NEOC fraction was significantly higher in SN (54.9\%) than in $\mathrm{SC}$ where it was $44.2 \%$ or in $\mathrm{CG}$ where it was $43.3 \%$. This larger fraction in $\mathrm{SN}$, which is a medium with less biological activity, probably shows that it is a little-evolved fraction. According to Almendros et al. (1996), this fraction (called "insolubilisation humin") is usually made up of recalcitrant microbial and plant biopolymers, originally insoluble and strongly aliphatic, which is concentrated in the insoluble fraction of the SOM. It is not necessarily generated by long complex decomposition processes (López-Sangil and Rovira, 2013), and therefore, the results indicate a less mature humus in the acid environment of SN than in the other two areas.

Of the fundamental HA elemental composition ratios, the $\mathrm{H} / \mathrm{C}$ ratio, which is related to aliphaticity, and the atomic $\mathrm{O} / \mathrm{C}$ ratio, which is a direct reference to the degree of oxidation of the humic acid molecule and its carboxyl functional groups (Stevenson, 1994; Senesi et al., 2003), only the last ratio showed higher significant level of oxidation in samples from SC (0.64) and CG (0.63) than SN (0.56).

The $\mathrm{E}_{4} / \mathrm{E}_{6}$ ratio of soil $\mathrm{HA}$ decreases when the condensation and aromaticity of the humic substances rise and with increasing molecular weight (Stevenson, 1994; Fuentes et al., 2006), which is typical of more mature, more evolved organic materials, and is therefore useful as a humification indicator. The $\mathrm{E}_{4} / \mathrm{E}_{6}$ ratio did not reveal significant differences in the three sample zones, although the group means were somewhat lower in $\mathrm{CG}$ and $\mathrm{SC}$; are consistent with those commonly found in temperate areas (Oyonarte et al., 1994). The visible derivatographic spectroscopy of HA studied highlights valleys near $620 \mathrm{~nm}, 570 \mathrm{~nm}$ and $528 \mathrm{~nm}\left(\mathrm{D}_{620}, \mathrm{D}_{570}\right.$ and $\left.\mathrm{D}_{528}\right)$. These diagnostic spectral bands suggest the presence of perylenequinonic pigments derived from fungi (Oyonarte et al., 1994; Almendros et al., 2005). Table 3 shows the mean intensities of these bands in which differences may be observed, although not significant when grouping the samples by sampling zone, and which are generally higher in the basic mediums in SC and CG. In SN, some soil microbiological conditions are less favourable for these microbial metabolites. The constant presence of these substances might be considered characteristic of the humification processes in Mediterranean ecosystems (SánchezMarañón et al., 2002; Miralles et al., 2007; Miralles et al., 2012), playing a role in the accumulation of stable $\mathrm{C}$ forms in soil.

Assignment of the main infrared spectral bands in humic substances is primarily based on Haberhauer and Gerzabek (2001), Madari et al. (2006) and Tatzber et al. (2007). As shown in Table 3, the intensity of the $2920 \mathrm{~cm}^{-1}$ band implies significantly less presence of aliphatic $\mathrm{C}-\mathrm{H}$ groups in $\mathrm{CG}$ in contrast with the clearly more aliphatic HA in SN. An intermediate mean was found in SC. With the advance of humification in the soil, humic substances become more aromatic and less aliphatic (Ding et al., 2002). 
Table 3. Selected parameters of the Soil Organic Matter in Mediterranean ecosystems soils (SE Spain). Grouping criterion: Sampling zone

\begin{tabular}{|c|c|c|c|c|c|}
\hline & SN(a) & $\mathbf{S C}(b)$ & $\mathbf{C G}(\mathrm{c})$ & P-value & $(*)$ \\
\hline Sample size & 12 & 12 & 12 & - & - \\
\hline Total organic carbon (OC), \% & 2.63 & 3.31 & 1.77 & 0.039 & $\mathrm{bc}$ \\
\hline $\begin{array}{l}\text { Humus fractions, g C }\left(100 \mathrm{~g} \text { soil } \mathrm{C}^{-1}\right. \\
\text { Free Organic Matter (FOM) } \\
\text { HA/FA ratio } \\
\text { Total extractable humin (HUMIN) } \\
\text { Non-extractable organic carbon (NEOC) }\end{array}$ & $\begin{array}{c}7.55 \\
0.8 \\
2.02 \\
54.95\end{array}$ & $\begin{array}{c}1.94 \\
0.7 \\
15.24 \\
44.19\end{array}$ & $\begin{array}{c}4.51 \\
1.0 \\
17.81 \\
43.33\end{array}$ & $\begin{array}{l}0.002 \\
0.218 \\
0.000 \\
0.006\end{array}$ & $\begin{array}{l}a b, a c \\
- \\
a b, a c \\
a b, a c\end{array}$ \\
\hline $\begin{array}{l}\text { Elemental composition of } \mathbf{H A} \\
\text { Atomic } \mathrm{H} / \mathrm{C} \text { ratio } \\
\text { Atomic } \mathrm{O} / \mathrm{C} \text { ratio }\end{array}$ & $\begin{array}{l}1.41 \\
0.56\end{array}$ & $\begin{array}{l}1.47 \\
0.64\end{array}$ & $\begin{array}{l}1.43 \\
0.63\end{array}$ & $\begin{array}{l}0.594 \\
0.003\end{array}$ & ab, ac \\
\hline $\begin{array}{l}\text { Visible spectroscopy measurements in HA } \\
E_{4} / E_{6} \text { ratio } \\
D_{620}(\text { visible derivatographic spectroscopy, } A U) \\
D_{570}(") \\
D_{528}(\text { " ) }\end{array}$ & $\begin{array}{l}4.57 \\
0.016 \\
0.013 \\
0.017\end{array}$ & $\begin{array}{c}4.52 \\
0.018 \\
0.014 \\
0.021\end{array}$ & $\begin{array}{l}4.35 \\
0.017 \\
0.014 \\
0.019\end{array}$ & $\begin{array}{l}0.738 \\
0.868 \\
0.812 \\
0.325\end{array}$ & $\begin{array}{l}- \\
- \\
-\end{array}$ \\
\hline $\begin{array}{l}\text { Infrared spectroscopy of HA } \\
\text { (relative optical density of the main bands) } \\
2920 \mathrm{~cm}^{-1} \\
1660 \mathrm{~cm}^{-1} \\
1510 \mathrm{~cm}^{-1} \\
1460 \mathrm{~cm}^{-1} \\
1420 \mathrm{~cm}^{-1} \\
1380 \mathrm{~cm}^{-1} \\
1080 \mathrm{~cm}^{-1}\end{array}$ & $\begin{array}{l}0.80 \\
0.83 \\
0.78 \\
0.89 \\
0.64 \\
0.65 \\
0.45\end{array}$ & $\begin{array}{l}0.73 \\
0.77 \\
0.63 \\
0.74 \\
0.63 \\
0.63 \\
0.42\end{array}$ & $\begin{array}{l}0.66 \\
0.70 \\
0.61 \\
0.70 \\
0.65 \\
0.65 \\
0.40\end{array}$ & $\begin{array}{l}0.009 \\
0.087 \\
0.033 \\
0.012 \\
0.775 \\
0.827 \\
0.288\end{array}$ & $\begin{array}{c}\mathrm{ac} \\
\mathrm{ac} \\
\mathrm{ac}, \mathrm{ab} \\
\mathrm{ac}, \mathrm{ab} \\
- \\
- \\
-\end{array}$ \\
\hline $\begin{array}{l}\text { Soil respiratory activity } \\
\text { Total mineralization coefficient (TMC), } \\
\mathrm{mg} \mathrm{C}(100 \mathrm{~g} \text { soil C })^{-1} \text { day }^{-1}\end{array}$ & 1.36 & 1.19 & 1.33 & 0.790 & - \\
\hline
\end{tabular}

SN: Sierra Nevada N.P. (acid metamorphic substratum); SC: Sierra de Cazorla N.P. (calcareous substratum); CG: Cabo de Gata N.P. (calcareous/volcanic substratum). AU: absorbance units. ${ }^{*}$ ) Groups denote statistically significant differences at $p<0.05$ level (LSD procedure).

These processes result in the concentration of condensed aromatic structures and the elimination of lateral chains, and macromolecules become more stable and increasingly more resistant to biodegradation (Stevenson, 1994). Aliphatic and N-containing groups are assigned to the $1660 \mathrm{~cm}^{-1}$ band. High intensities in this area of the spectra indicate high content in littleevolved forms of nitrogen, mainly characterized by higher protein content. In this band, optical density is significantly lower in $\mathrm{CG}$, highest in $\mathrm{SN}$ and intermediate in SC. The less-stabilized HA fraction showed a similar trend according to the band at $1510 \mathrm{~cm}^{-}$ 1, where CG intensity was the lowest, followed by SC, and $\mathrm{SN}$ was the highest. This again suggests that $\mathrm{SN}$ is the least favourable environment for humus evolution complexity. The presence of lignin can usually be detected by characteristic spectroscopic patterns at around 1460, 1420 and $1380 \mathrm{~cm}^{-1}$ (Almendros et al., 2003). Only the intensity at $1460 \mathrm{~cm}^{-1}$ (aliphatic $\mathrm{C}-\mathrm{H}$ groups) is sufficiently statistically significant to separate CG and SC, which have similar group means, from SN samples, which have much higher constituent 
lignin. Lignin decomposes slowly and is a recalcitrant fraction in soil (Sleutel et al., 2007). Thus, although the large amount present suggests less evolved humus, from the point of view of its persistence in soils, selective enrichment of recalcitrant molecule classes contained in plants, like lignin or phenols, is of interest. SN samples also showed higher intensities for the band at $1080 \mathrm{~cm}^{-1}$, typical of C-O and C-H deformations, which although not statistically significant, indicates the presence of polysaccharides or carbohydrate-like substances, reflecting the influence of recent plant material.

The in vitro respiratory activity, expressed as total mineralisation coefficients (TMC), provides an estimate of the intrinsic biodegradability of organic matter in soil and its degree of maturity and stability; being considered a key factor of humus quality in terms of soil C sequestration (Almendros et al., 2005). The organic matter TMC was very similar to what is commonly reported in temperate areas (Oyonarte et al., 1994). These results are somewhat, though not significantly, different from the groups studied, with a higher mean for $\mathrm{SN}$, where therefore, the organic matter accumulated is more biodegradable, i.e., more readily available to microorganisms. Also, there is a significant negative relationship between soil respiratory activity (TMC) and HA content $(\mathrm{r}=-0.517 ; p<0.01)$, which shows that this organic matter fraction is more intrinsically chemically recalcitrant, and its increase indicates stabilization of SOM.

The typical Mediterranean climate also characterizes mountain areas with cold winters and very dry summers. In $\mathrm{SN}$, the lower mean annual temperature and higher altitude (Table 1), combined with the acidity of the schistose substratum and low base saturation of the soils, might explain the differences in the progress of humification, with a higher resistance of their organic $\mathrm{C}$ to be transformed into more evolved forms by microbial activity. As suggested by Zeraatpishe and Khormali (2012), climate and parent material are the main factors responsible for SOM accumulation and decomposition. On the contrary, and coinciding with a previous study by Miralles et al. (2007), strong seasonal moisture changes typical of the continental Mediterranean climate, associated with high solar irradiation, especially intense in $\mathrm{CG}$, could be favouring the formation and maturation of HA observed in the latter. Also, and according to Djukic et al. (2010), higher pH (as in CG and SC, Table 2) implies favourable conditions for decomposition and may lead to higher humification and accumulation of aromatic structures and HA stability.

\subsection{Influence of the sampling zone and vegetation type on soil organic matter quality}

Table 4 shows the general characteristics of SOM taking into account the lithology and climate conditions along with vegetation type. The humus fractions with statistical significance between the groups are FOM, HUMIN and NEOC. The highest average FOM fraction content $(11.7 \%)$ is observed in the samples beneath Pinus species reforestation in an acid medium (SNR), the biogeochemical conditions of which would favour a higher content in plant residues. The HUMIN fraction enables the samples from SC and CG to be differentiated from SN, which with clearly lower averages, would have less capacity to form stable organic-mineral complexes. The NEOC fraction is the main fraction in the samples beneath reforestations with Pinus both in basic and in acid environments (SCR and SNR) as well as beneath forest with Quercus in an acid environment (SNB). Therefore, those samples taken from soils subjected to reforestation are clearly separated by their lower humification.

The atomic $\mathrm{O} / \mathrm{C}$ ratio, from the elemental composition of the HA and the only one that is statistically significant, suggests that the highest carboxylation in the HA comes from the SC and CG sites regardless of the type of vegetation.

It may be concluded that scrubland, regardless of which area it is in (SNM, SCM and CGM), has lower $\mathrm{E}_{4} / \mathrm{E}_{6}$ ratios, though not statistically significant, whilst reforested vegetation tends to have a higher ratio (SNR and SCR), and therefore, a tendency to less macromolecular complexity in the HA. 
Table 4. Selected parameters of the Soil Organic Matter in Mediterranean ecosystems soils (SE Spain). Grouping criterion: Sampling zone and vegetation type

\begin{tabular}{|c|c|c|c|c|c|c|c|c|c|}
\hline & SNB(a) & SNR(b) & SNM(c) & $\operatorname{SCB}(d)$ & $\operatorname{SCR}(\mathrm{e})$ & $\operatorname{SCM}(f)$ & CGM(g) & P-value & $(*)$ \\
\hline Sample size & 4 & 4 & 4 & 4 & 4 & 4 & 12 & - & - \\
\hline Total organic carbon (OC), \% & 3.75 & 1.78 & 2.36 & 4.15 & 3.07 & 2.70 & 1.77 & 0.047 & $\mathrm{dg}, \mathrm{ag}, \mathrm{bd}, \mathrm{ab}$ \\
\hline $\begin{array}{l}\text { Humus fractions, g C }(100 \mathrm{~g} \text { soil C })^{-1} \\
\text { Free Organic Matter (FOM) } \\
\text { HA/FA ratio }\end{array}$ & $\begin{array}{c}6.45 \\
0.8\end{array}$ & $\begin{array}{c}11.71 \\
0.7\end{array}$ & $\begin{array}{c}4.45 \\
0.8\end{array}$ & $\begin{array}{c}2.20 \\
0.6\end{array}$ & $\begin{array}{c}1.21 \\
0.6\end{array}$ & $\begin{array}{c}2.40 \\
0.7\end{array}$ & $\begin{array}{c}4.51 \\
1.0\end{array}$ & $\begin{array}{l}0.000 \\
0.760\end{array}$ & bg, bd, bf, ae, be, ab, bc \\
\hline Total extractable humin (HUMIN) & 1.91 & 2.10 & 2.05 & 14.87 & 14.52 & 16.32 & 17.81 & 0.000 & $\begin{array}{c}\text { ag, cg, bg, ad, cd, bd, af, cf, bf, } \\
\text { ae, ce, be }\end{array}$ \\
\hline Non-extractable organic carbon (NEOC) & 59.28 & 56.68 & 48.88 & 38.24 & 52.68 & 41.66 & 43.33 & 0.006 & ag, bg, de, ad, bd, af, bf \\
\hline $\begin{array}{l}\text { Elemental composition of } \mathbf{H A} \\
\text { Atomic } \mathrm{H} / \mathrm{C} \text { ratio } \\
\text { Atomic } \mathrm{O} / \mathrm{C} \text { ratio }\end{array}$ & $\begin{array}{l}1.41 \\
0.58\end{array}$ & $\begin{array}{l}1.40 \\
0.56\end{array}$ & $\begin{array}{l}1.43 \\
0.54\end{array}$ & $\begin{array}{l}1.46 \\
0.63\end{array}$ & $\begin{array}{l}1.45 \\
0.65\end{array}$ & $\begin{array}{l}1.50 \\
0.63\end{array}$ & $\begin{array}{l}1.43 \\
0.63\end{array}$ & $\begin{array}{l}0.972 \\
0.059\end{array}$ & $\mathrm{cg}, \mathrm{bg}, \mathrm{cd}, \mathrm{cf}, \mathrm{ce}, \mathrm{be}$ \\
\hline $\begin{array}{l}\text { Visible spectroscopy measurements in HA } \\
E_{4} / E_{6} \text { ratio } \\
D_{620}(\text { visible derivatographic spectroscopy, AU) } \\
D_{570}(") \\
D_{528}(")\end{array}$ & $\begin{array}{c}4.60 \\
0.014 \\
0.011 \\
0.014\end{array}$ & $\begin{array}{l}4.87 \\
0.012 \\
0.010 \\
0.013\end{array}$ & $\begin{array}{l}4.24 \\
0.022 \\
0.017 \\
0.022\end{array}$ & $\begin{array}{l}4.71 \\
0.016 \\
0.013 \\
0.019\end{array}$ & $\begin{array}{l}4.83 \\
0.015 \\
0.012 \\
0.016\end{array}$ & $\begin{array}{l}4.25 \\
0.021 \\
0.016 \\
0.029\end{array}$ & $\begin{array}{l}4.35 \\
0.017 \\
0.014 \\
0.019\end{array}$ & $\begin{array}{l}0.748 \\
0.149 \\
0.119 \\
0.037\end{array}$ & $\begin{array}{c}- \\
\text { bf, bc } \\
\text { bf, ac, bc } \\
\text { fg, df, ef, af, bf }\end{array}$ \\
\hline $\begin{array}{l}\text { Infrared spectroscopy of HA } \\
\text { (relative optical density of the main bands) } \\
2920 \mathrm{~cm}^{-1} \\
1660 \mathrm{~cm}^{-1} \\
1510 \mathrm{~cm}^{-1} \\
1460 \mathrm{~cm}^{-1} \\
1420 \mathrm{~cm}^{-1} \\
1380 \mathrm{~cm}^{-1} \\
1080 \mathrm{~cm}^{-1}\end{array}$ & $\begin{array}{l}0.83 \\
0.86 \\
0.78 \\
0.89 \\
0.66 \\
0.64 \\
0.44\end{array}$ & $\begin{array}{l}0.81 \\
0.91 \\
0.97 \\
1.02 \\
0.69 \\
0.70 \\
0.51\end{array}$ & $\begin{array}{l}0.76 \\
0.72 \\
0.60 \\
0.76 \\
0.65 \\
0.60 \\
0.39\end{array}$ & $\begin{array}{l}0.76 \\
0.80 \\
0.65 \\
0.76 \\
0.67 \\
0.64 \\
0.43\end{array}$ & $\begin{array}{l}0.70 \\
0.69 \\
0.59 \\
0.73 \\
0.67 \\
0.63 \\
0.39\end{array}$ & $\begin{array}{l}0.74 \\
0.80 \\
0.67 \\
0.72 \\
0.68 \\
0.63 \\
0.44\end{array}$ & $\begin{array}{l}0.66 \\
0.70 \\
0.61 \\
0.70 \\
0.67 \\
0.65 \\
0.40\end{array}$ & $\begin{array}{l}0.104 \\
0.119 \\
0.007 \\
0.027 \\
0.833 \\
0.521 \\
0.163\end{array}$ & $\begin{array}{c}\text { ag, bg } \\
\text { bg, be } \\
\text { bg, bd, bf, be, bc } \\
\text { ag, bg, bd, bf, be, bc } \\
- \\
\text { bc } \\
\text { bg, be, bc }\end{array}$ \\
\hline 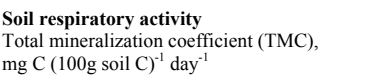 & 1.32 & 1.86 & 0.89 & 1.16 & 1.43 & 0.98 & 1.33 & 0.384 & $\mathrm{bc}$ \\
\hline
\end{tabular}

SN: Sierra Nevada N.P. (acid metamorphic substratum); SC: Sierra de Cazorla N.P. (calcareous substratum); CG: Cabo de Gata N.P. (calcareous/volcanic substratum); B: natural forests; R: pine reforestations; M: scrublands. AU: absorbance units. (*) Groups denote statistically significant differences at $p<0.05$ level (LSD procedure).

Statistically significant differences were observed in the intensities of $\mathrm{D}_{620}, \mathrm{D}_{570}$ and $\mathrm{D}_{528}$ with derivatographic spectroscopy, indicating, as mentioned above, the presence of perylenequinonic pigments derived from fungi. There are more presence of these substances in the samples from scrubland vegetation, mainly in SNM and SCM. Reforestation in the acid environment (SNR) does not appear to favour the development of the microbial populations responsible for the concentration of quinoid pigments.

Some interesting differences amongst the groups were highlighted by IR spectroscopy of the HA. The contribution of aliphatic C-H vibrations $\left(2920 \mathrm{~cm}^{-1}\right.$ band) to the structure of HA is larger in the reforested (SNR) and Quercus forest (SNB) areas, and lower in the reforested areas in $\mathrm{SC}$, and even lower in the scrubland in CG, confirming the pattern of less advanced humification in the acid environment of Sierra Nevada. Significantly higher intensities of the bands at $1660 \mathrm{~cm}^{-1}, 1510 \mathrm{~cm}^{-1}$ and $1080 \mathrm{~cm}^{-1}$, are observed in the SNR samples, the group with organic matter with the least transformation. A clear and significant difference is found in the samples from beneath reforested pine trees in an acid medium, in which the high intensities of the peaks at $1460 \mathrm{~cm}^{-1}$ and $1380 \mathrm{~cm}^{-1}$ (accumulation of lignin in the HA) are an indicator of less evolved humic substances. The intensity of these bands also shows a clear reduction in basic medium. Figure 2 shows the representative resolution-enhanced IR spectra of a HA sample from SNR (a), coinciding with the highest $\mathrm{E}_{4} / \mathrm{E}_{6}$ ratio, and from CGM (b), coinciding with the lowest $\mathrm{E}_{4} / \mathrm{E}_{6}$ ratio. 


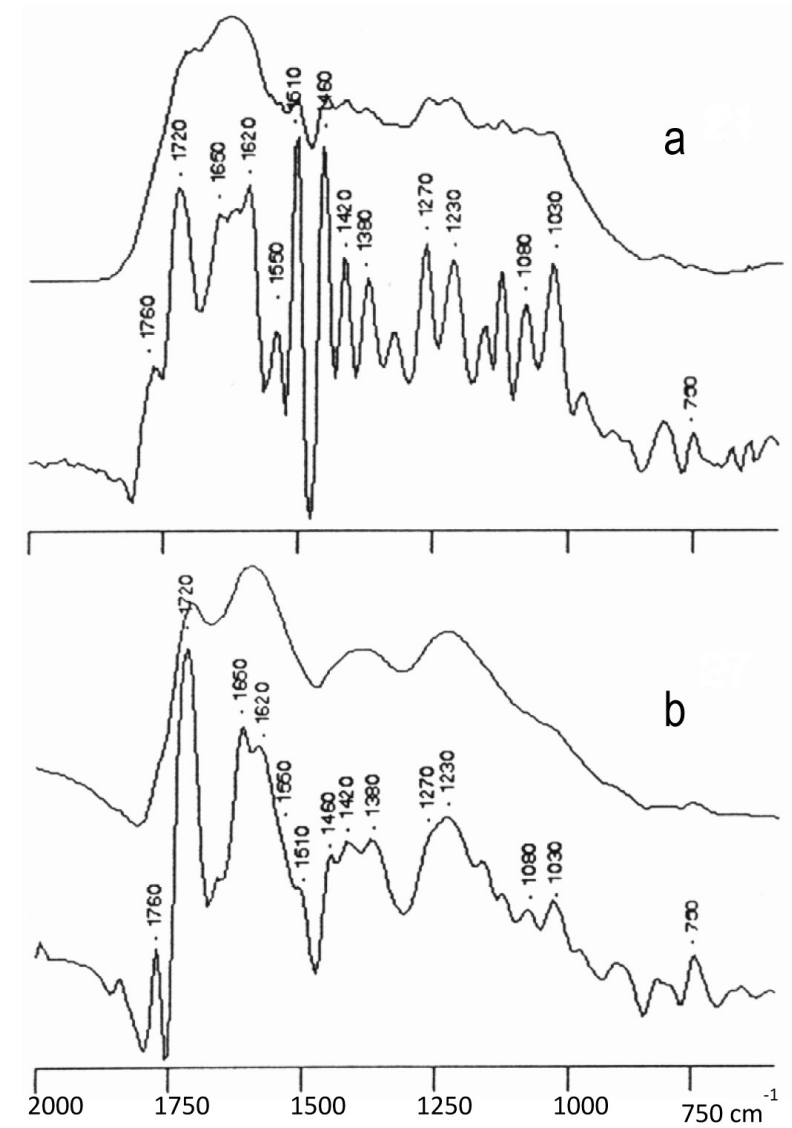

Figure 2. FTIR spectra and resolution-enhanced IR spectra (bottom) of the $2000-600 \mathrm{~cm}^{-1}$ region, representative of humic acids from SNR (a) and CGM (b) ecosystems soils.

The average TMC is higher in the SNR group (1.86 $\operatorname{mg~C}(100 \mathrm{~g} \text { soil } \mathrm{C})^{-1}$ day $\left.^{-1}\right)$, hence the samples beneath Pinus in an acid medium are less stable and their organic material tends to be more biodegradable.

In general, the HA sampled from the soils beneath Quercus are more evolved than under Pinus, with less humification observed overall beneath the latter. Results would seem to indicate that the areas reforested with Pinus species have a more negative impact on the acid SN environment than on the basic $\mathrm{SC}$ environment. In the latter, vegetal remains from pine trees have undergone a deeper transformation and more efficient humification by the soil environment. In this sense, a large percentage of the area reforested with pine trees in SC may have been more efficiently stabilised than in $\mathrm{SN}$, thereby achieving a certain balance with the environmental conditions due to more favourable geochemical conditions and biological activity. A biogenic background representative of the original Quercus vegetation could be overlapping the organic compounds derived from Pinus reforestations and would explain the scant analytical differences 
between samples beneath natural forests (SCB) and beneath reforested areas (SCR). All the scrublands, regardless of the edaphoclimatic zone they belonged to, were observed to tend toward generation of more highly evolved humus. Moreover, the scrubland on the basic substratum in the Cabo de Gata N.P. (CGM), showed a more favourable tendency in the evolution of the organic fraction, possibly affected by the mild winter temperatures, the effect of hidden rain, and to the good adaptation of the scrubland to the ecological conditions present in the area.
In the samples from the basic substratum, a tendency to formation of a somewhat more evolved type of humus was observed. This may be due to the greater biological activity associated with the type of vegetation (including pines in SC) and a thicker and more varied vegetation which intensifies the biogeochemical cycle by supplying more easily decomposable remains, and to the type of lithological substratum that releases nutrients into the medium favouring biological activity of both micro-organisms and plants.

Table 5. Selected parameters of the Soil Organic Matter in Mediterranean ecosystems soils (SE Spain). Grouping criterion: vegetation type

\begin{tabular}{|c|c|c|c|c|c|}
\hline & $\mathbf{B}(\mathrm{a})$ & $\mathbf{R}(b)$ & $\mathbf{M}(\mathrm{c})$ & P-value & $(*)$ \\
\hline Sample size & 8 & 8 & 20 & - & - \\
\hline Total organic carbon (OC), \% & 3.95 & 2.43 & 2.08 & 0.008 & $\mathrm{ab}, \mathrm{ac}$ \\
\hline $\begin{array}{l}\text { Humus fractions, g C (100g soil C) } \\
\text { Free Organic Matter (FOM) } \\
\text { HA/FA ratio } \\
\text { Total extractable humin (HUMIN) } \\
\text { Non-extractable organic carbon (NEOC) }\end{array}$ & $\begin{array}{c}4.34 \\
0.7 \\
8.39 \\
48.76\end{array}$ & $\begin{array}{c}6.46 \\
0.6 \\
8.31 \\
54.68\end{array}$ & $\begin{array}{c}4.08 \\
0.9 \\
14.36 \\
44.11\end{array}$ & $\begin{array}{l}0.376 \\
0.344 \\
0.118 \\
0.044\end{array}$ & $\begin{array}{l}- \\
- \\
- \\
\text { bc }\end{array}$ \\
\hline $\begin{array}{l}\text { Elemental composition of } \mathbf{H A} \\
\text { Atomic } \mathrm{H} / \mathrm{C} \text { ratio } \\
\text { Atomic } \mathrm{O} / \mathrm{C} \text { ratio }\end{array}$ & $\begin{array}{l}1.43 \\
0.60\end{array}$ & $\begin{array}{l}1.43 \\
0.61\end{array}$ & $\begin{array}{l}1.45 \\
0.61\end{array}$ & $\begin{array}{l}0.948 \\
0.916\end{array}$ & - \\
\hline $\begin{array}{l}\text { Visible spectroscopy measurements in HA } \\
E_{4} / E_{6} \text { ratio } \\
D_{620} \text { (visible derivatographic spectroscopy, AU) } \\
D_{570}(") \\
D_{528}(")\end{array}$ & $\begin{array}{l}4.53 \\
0.015 \\
0.012 \\
0.017\end{array}$ & $\begin{array}{l}4.85 \\
0.013 \\
0.011 \\
0.014\end{array}$ & $\begin{array}{l}4.31 \\
0.019 \\
0.015 \\
0.022\end{array}$ & $\begin{array}{l}0.173 \\
0.081 \\
0.032 \\
0.030\end{array}$ & $\begin{array}{l}- \\
\mathrm{bc} \\
\mathrm{bc} \\
\mathrm{bc}\end{array}$ \\
\hline $\begin{array}{l}\text { Infrared spectroscopy of HA } \\
\text { (relative optical density of the main bands) } \\
2920 \mathrm{~cm}^{-1} \\
1660 \mathrm{~cm}^{-1} \\
1510 \mathrm{~cm}^{-1} \\
1460 \mathrm{~cm}^{-1} \\
1420 \mathrm{~cm}^{-1} \\
1380 \mathrm{~cm}^{-1} \\
1080 \mathrm{~cm}^{-1}\end{array}$ & $\begin{array}{l}0.80 \\
0.83 \\
0.71 \\
0.83 \\
0.64 \\
0.64 \\
0.44\end{array}$ & $\begin{array}{l}0.76 \\
0.81 \\
0.78 \\
0.88 \\
0.66 \\
0.67 \\
0.45\end{array}$ & $\begin{array}{l}0.69 \\
0.73 \\
0.62 \\
0.71 \\
0.63 \\
0.63 \\
0.41\end{array}$ & $\begin{array}{l}0.093 \\
0.166 \\
0.085 \\
0.046 \\
0.580 \\
0.485 \\
0.335\end{array}$ & $\begin{array}{c}\mathrm{ac} \\
- \\
\mathrm{bc} \\
\mathrm{bc} \\
- \\
- \\
-\end{array}$ \\
\hline $\begin{array}{l}\text { Soil respiratory activity } \\
\text { Total mineralization coefficient (TMC), } \\
\mathrm{mg} \mathrm{C}(100 \mathrm{~g} \text { soil C })^{-1} \text { day }^{-1}\end{array}$ & 1.24 & 1.65 & 1.17 & 0.178 & - \\
\hline
\end{tabular}

B: natural forests; R: pine reforestations; M: scrublands. AU: absorbance units. (*) Groups denote statistically significant differences at $p<0.05$ level (LSD procedure). 


\subsection{Influence of the vegetation type on soil organic matter quality}

When the characteristics of the SOM of the samples were compared by vegetation type (Table 5) no great differences among the groups were observed. Nonetheless, some differences are worthy of mention. The NEOC fraction of the humus turns out to be significantly higher in the samples from beneath pine trees (R), which would confirm their lesser evolution. Furthermore, although not statistically significant, the samples beneath scrubland (M) have a larger proportion of carbon in the HUMIN fraction, higher HA/FA ratio and lower proportion of FOM than in the other two plant formations.

The visible spectra reveal less condensation and lower molecular weight of the humic substances underneath reforestations (R), shown by their highest extinction $\mathrm{E}_{4} / \mathrm{E}_{6}$ ratio. The concentration of fungal pigments in HA is related to the type of vegetation, and turns out to be significantly higher both in scrubland (M), where content reaches a maximum, and in natural forest (B), both plant formations in which the microbial synthesis mechanisms responsible for the accumulation of perylenequinonic pigments are intensified in the humus formation. Amongst the main IR spectra bands related to the presence of lignin, the $1460 \mathrm{~cm}^{-1}$ band for the samples from beneath pines $(\mathrm{R})$ is especially significant. Higher level of aliphaticity $\left(2920 \mathrm{~cm}^{-1}\right)$ and a less stabilized HA fraction $\left(1510 \mathrm{~cm}^{-1}\right)$ were also found in the samples beneath Quercus (B) and Pinus (R). Hence, several of the characteristics analysed indicate that the organic remains of soils beneath Quercus were more decomposed than those from coniferous forests, which would enrich the humic substances in recalcitrant organic components giving rise to limited decomposition.

The results give an idea of more favourable humification progress beneath scrubland vegetation (M) as confirmed by some variables such as FOM, HA/FA, HUMIN, $1660 \mathrm{~cm}^{-1}$ and $1080 \mathrm{~cm}^{-1}$ IR spectra, and TMC, although not statistically significant. The wide plant diversity in the scrubland, could affect below-ground diversity and greater microhabitat heterogeneity, leading to an increase in decomposition rates and evolution of humus. This implies that the scrubland might provide greater stability for the surface horizons of the soils, and therefore, for the related ecosystems, than the other plant formations studied.

\subsection{Potential of spectroscopic data for assessing variation in humus}

The results show the potential of spectroscopic data for evaluating the mechanisms of humification that lead to maturation of HA. Characterisation of the extent of humification of humic substances could also be of special interest, because, according to Santos et al. (2010), more humified substances are generally more chemically stable, increasing the residence time of organic matter in the environment and consequently improving soil quality.

The optical density of HA solutions adjusted to a constant concentration is frequently taken as the most valuable surrogate indicator of aromaticity and maturation of humic matter (Almendros et al., 2003). Following this criterion, and analysing the main HA spectroscopic data, a significant correlation is observed in which the higher the $\mathrm{E}_{4}$ optical density, the higher the fungal pigment content (Figure 3a), mainly with respect to the intensity at $528 \mathrm{~nm}$ in the second derivative spectra. This relationship means that the increase in aromaticity and condensation with humification in the samples is a product of intensified biogeochemical activity with accumulation of microbially reworked HA and microbial metabolites.

When the IR band at $1460 \mathrm{~cm}^{-1}$ (the most significant in the lignin pattern) is correlated with the $\mathrm{E}_{4}$ optical density (Figure $3 b$ ), or the $\mathrm{E}_{4} / \mathrm{E}_{6}$ ratio (Figure $3 \mathrm{c}$ ), a significant negative correlation is observed in the first case, and as expected, positive in the second. Hence, in the sites under study, a clear trend towards a less dark color is observed in those HA with better defined 
lignin pattern. The tendency of less humification with accumulation of lignin is validated by a positive correlation between the IR band at $1460 \mathrm{~cm}^{-1}$, and among others alkyl compounds, with the protein IR band at $1660 \mathrm{~cm}^{-1}$ (Figure 3d). These results show a decrease in humification in samples where accumulation of plant macromolecules, such as lignin structures, predominates, and is the major humification mechanism. The representation in space defined by the first two factors found with principal component analysis (Figure 4) showed two clusters based on quality descriptors interpreted as different humification mechanisms.

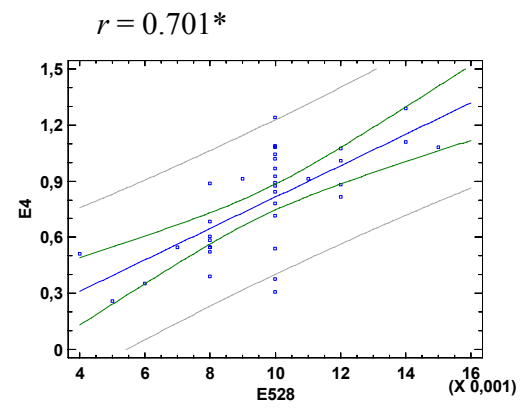

a

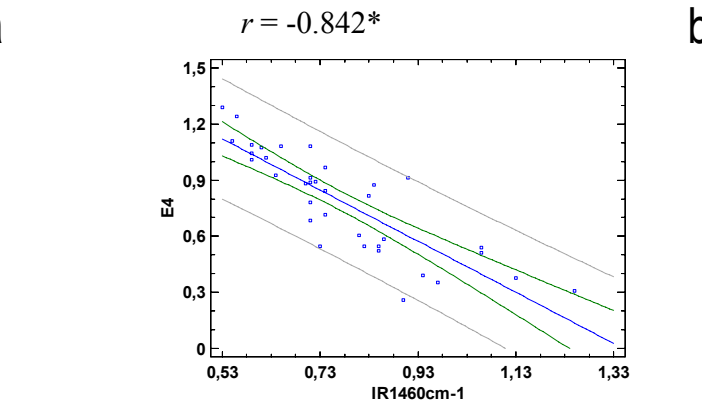

C
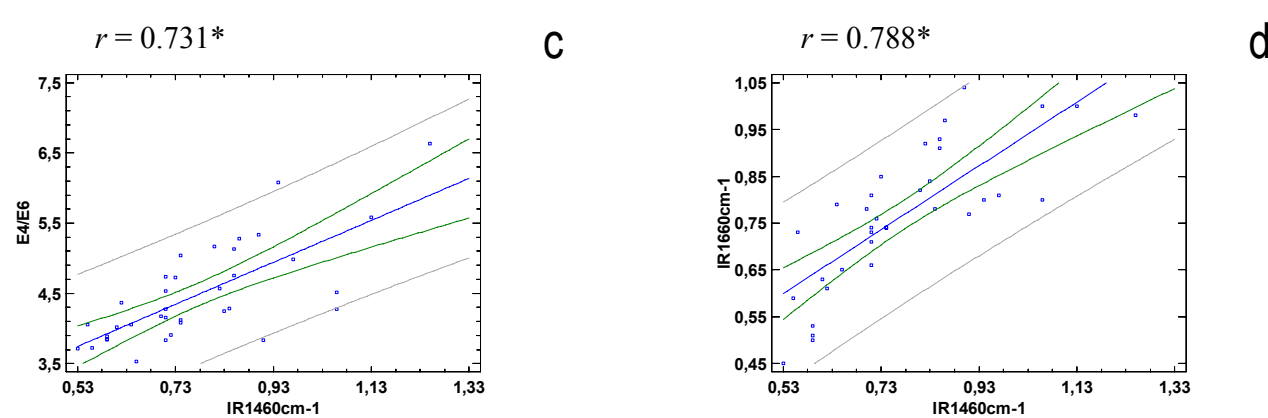

The right-hand cluster showed descriptors related to oxidation and microbial quinoid content in the HA, and degree of humification (HA/FA ratio), i.e., with high biogeochemical organic matter transformation and more advanced and complex stages of humification. The left-hand cluster compiled all descriptors related with high organic carbon (OC, NEOC and FOM) and raw humus associated with slightly altered macromolecules in the HA fraction (higher aliphaticity, strong lignin patterns, and higher polysaccharides and protein contents). Less stability of the organic matter expressed as TMC would have to be stressed in this cluster.

b

Figure 3. Correlations between the main spectroscopic parameters to establish the origin of humus variation. *Statistical significance level: $p$-value $<0.001 ; \mathrm{n}=36$. 


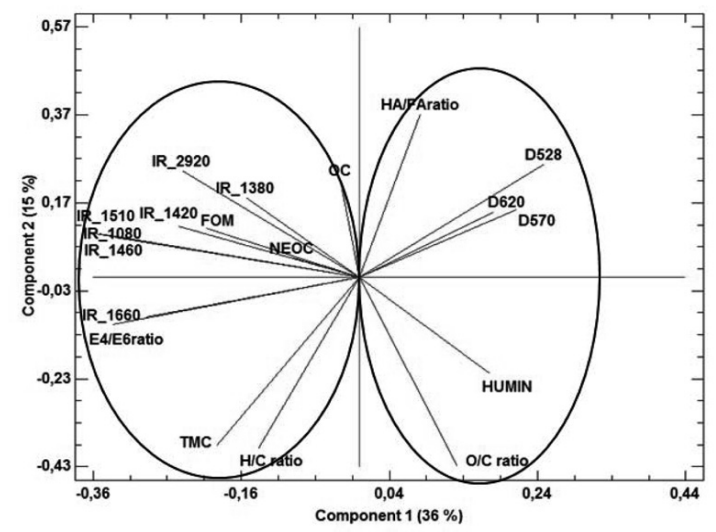

Figure 4. 2D scatter plot of PCA and variance explained (\%) by each component of soil organic matter quality parameters. Parameter abbreviations from Tables 3, 4 and 5.

\section{Conclusions}

The set of analyses used to characterize the chemical composition and quality of the organic matter in the environments studied suggests uniform results of humification, probably due to the Mediterranean climate, which has strong seasonal changes that act on Mediterranean vegetation in a unique way that is well adapted to the different parent materials (calcareous, acid metamorphic and calcareous/ volcanic rocks). Differences among the sampling zones indicate that the acid environment in Sierra Nevada, with an acid schistose substratum and harsh climate conditions, can be considered the least favourable for a higher complexity in humus evolution. In this acid environment in Sierra Nevada, the species of Pinus showed lower efficiency in the humification mechanisms, clearly explained by the physicochemical nature of the humic substances. Moreover, in the basic environment in Sierra de Cazorla, the differences between the samples beneath natural forest and reforested areas are scant, as a result of some more favourable geochemical conditions and biological activity, as compared to the acid environment in Sierra Nevada.
The analysis of the samples beneath the three types of vegetation reveal a certain differentiation in the characteristics of the humus according to the nature of the organic remains, much less obvious differences than would be expected bearing in mind the different characteristics of the plant remains and vegetation types, interpreted as a certain resilience of the humus formations in the sites under study. Beneath Pinus vegetation, the humus proves to be less evolved and stable than in natural forests and scrubland. Results would seem to indicate that the scrubland is capable of creating humus with more favourable characteristics for greater stability in the surface horizons of the soils studied.

These results provide valuable information on sustainability in vegetation management practices considering lithology and climate conditions in areas with high risk of degradation, such as Mediterranean environments.

\section{Acknowledgments}

Authors are grateful to Spanish PAIDI funding for Research groups RNM127 and FQM363. 


\section{References}

Almendros, G., Guadalix, M.E., González-Vila, F.J., Martín, F. 1996. Preservation of aliphatic macromolecules in soil humins. Org. Geochem. 24, 651-659.

Almendros, G., Kgathi, D., Sekhwela, M., Zancada, M.C., Tinoco, P., Pardo, M.T. 2003. Biogeochemical assessment of resilient humus formations from virgin and cultivated Northern Botswana soils. J. Agric. Food Chem. 51, 43214330.

Almendros, G., Zancada, M.C., Pardo, M.T. 2005. Land use and soil carbon accumulation patterns in South African savanna ecosystems. Biol. Fertil. Soils. 41, 173-181.

Aranda, V., Ayora-Cañada, M.J., Domínguez-Vidal, A., Martín-García, J.M., Calero, J., Delgado, R., Verdejo, T., González-Vila, F.J. 2011. Effect of soil type and management (organic vs. conventional) on soil organic matter quality in olive groves in a semi-arid environment in Sierra Mágina Natural Park (S Spain). Geoderma. 164, 54-63.

Caravaca, F., Masciandaro, G., Ceccanti, B. 2002. Land use in relation to soil chemical and biochemical properties in a semiarid Mediterranean environment. Soil Till. Res. 68, 23-30.

Castro, J., Zamora, R., Hódar, J.A., Gómez, J.M., Gómez-Aparicio, L. 2004. Benefits of using shrubs as nurse plants for reforestation in Mediterranean mountains: a 4-year study. Restor. Ecol. 12, 352-358.

Delgado, R., Sánchez-Marañón, M., Martín-García, J.M., Aranda, V., Serrano-Bernardo, F., Rosúa, J.L. 2007. Impact of ski pistes on soil properties: a case study from a mountainous area in the Mediterranean region. Soil Use Manage. 23, 269277.
Ding, G., Novak, J.M., Amarasiriwardena, D., Hunt, P.G., Xing, B. 2002. Soil organic matter characteristics as affected by tillage management. Soil Sci. Soc. Am. J. 66, 421-429.

Djukic, I., Zehetner, F., Tatzber, M., Gerzabek, M.H. 2010. Soil organic-matter stocks and characteristics along an Alpine elevation gradient. J. Plant Nutr. Soil Sci. 173, 30-38.

Fuentes, M., González-Gaitano, G., García-Mina, J.M. 2006. The usefulness of UV-visible and fluorescence spectroscopies to study the chemical nature of humic substances from soils and composts. Org. Geochem. 37, 1949-1959.

Haberhauer, G., Gerzabek, M.H. 2001. FTIRspectroscopy of soils. Characterization of soil dynamic processes. Trends Appl. Spectrosc. 3, 103-109.

Hill, J., Stellmes, M., Udelhoven, T., Röder, A., Sommer, S. 2008. Mediterranean desertification and land degradation Mapping related land use change syndromes based on satellite observations. Glob. Planet. Change. 64, 146-157.

Klute, A. 1986. Methods of soil analysis, Part 1, 2nd ed. Agron. Monogr., 9. ASA and SSSA, Madison, WI, USA, 1188 p.

Li, H., Pei, J.B., Wang, J.K., Li, S.Y., Gao, G.W. 2013. Organic carbon density and storage of the major black soil regions in Northeast China. J. Soil Sci. Plant Nutr. 13 (4), 883-893.

Lopez-Sangil, L., Rovira, P. 2013. Sequential chemical extractions of the mineral-associated soil organic matter: An integrated approach for the fractionation of organo-mineral complexes. Soil Biol. Biochem. $62,57-67$.

Madari, B.E., Reeves III, J.B., Machado, P.L.O.A., Guimarães, C.M., Torres, E., McCarty, G.W. 2006. Mid- and near-infrared spectroscopicSánchez- 
of soil compositional parameters and structural indices in two Ferralsols. Geoderma. 136, 245-259.

Miralles, I., Ortega, R., Sánchez-Marañón, M., Soriano, M., Almendros, G. 2007. Assessment of biogeochemical trends in soil organic matter sequestration in Mediterranean calcimorphic mountain soils. Soil Biol. Biochem. 39, 24592470 .

Miralles, I., Ortega, R., Almendros, G., Gil-Sotres, F., Trasar-Cepeda, C., Leirós, M.C., Soriano, M. 2012. Modifications of organic matter and enzymatic activities in response to change in soil use in semi-arid mountain ecosystems (southern Spain). Eur. J. Soil Sci. 63, 272-283.

Oyonarte, C., Pérez, A., Delgado, G., Delgado, R., Almendros, G. 1994. Factors affecting soil organic matter turnover in a Mediterranean ecosystems from Sierra de Gádor (Spain): An analytical approach. Commun. Soil Sci. Plant Anal. 25, 1929-1945.

Page, A.L., Miller, R.H., Keeney, D.R. 1982. Methods of soil analysis. Part 2, 2nd ed. Agron. Monogr., 9. ASA and SSSA, Madison, WI, USA, 1159 p.

Rosenfeld, A., Kak, A.C. 1982. Digital Picture Processing, Vol. I. Academic Press, NY, 435 p.

Rubio, J.L., Recatalá, L. 2006. The relevance and consequences of Mediterranean desertification including security aspects. In: W.G. Kepner, J.L. Rubio, D.A. Mouat, F. Pedrazzini (eds.). Desertification in the Mediterranean Region: a Security Issue. Springer, Netherlands, pp: 133-165.

Ruiz-Sinoga, J.D., Pariente, S., Romero-Diaz, A., Martinez-Murillo, J.F. 2012. Variability of relationships between soil organic carbon and some soil properties in Mediterranean rangelands under different climatic conditions (South of Spain). Catena 94, 17-25.
Sánchez-Marañón, M., Soriano, M., Delgado, G., Delgado, R. 2002. Soil quality in Mediterranean mountain environments: effects of land use change. Soil Sci. Soc. Am. J. 66, 948-958.

Santos, L.M., Simões, M.L., de Melo, W.J., Martin-Neto, L., Rodrigues-Pereira, E. 2010. Application of chemometric methods in the evaluation of chemical and spectroscopic data on organic matter from Oxisols in sewage sludge applications. Geoderma. 155, 121-127.

Senesi, N., D’Orazio, V., Ricca, G. 2003. Humic acids in the first generation of EUROSOILS. Geoderma. 116, 325-344.

Sevink, J., Verstraten, J.M., Jongejans, J. 1998. The relevance of humus forms for land degradation in Mediterranean mountainous areas. Geomorphology. 23, 285-292.

Sleutel, S., Kader, M.A., Leinweber, P., D'Haene, K., de Neve, S. 2007. Tillage management alters surface soil organic matter composition: a pyrolysis mass spectroscopy study. Soil Sci. Soc. Am. J. 71, 1620-1628.

Stevenson, F.J. 1994. Humus Chemistry. Genesis, Composition, Reactions. Wiley, NY, 496 p.

Stevenson, F.J., Cole, M.A. 1999. Cycles of Soil. Carbon, Nitrogen, Phosphorus, Sulfur, Micronutrients. Wiley, NY, 427 p.

Swift, R.S. 1996. Organic matter characterization (chap. 35). In: D.L. Sparks (eds.). Methods of soil analysis, Part 3, Chemical methods. Soil Sci. Soc. Am., Book Series No 5. ASA/SSSA, Inc., Madison, WI, pp: 1018-1020.

Tatzber, M., Stemmer, M., Spiegel, H., Katzlberger, C., Haberhauer, G., Mentler, A., Gerzabek, M.H. 2007. FTIR-spectroscopic characterization of humic acids and humin fractions obtained by advanced $\mathrm{NaOH}, \mathrm{Na}_{4} \mathrm{P}_{2} \mathrm{O}_{7}$, and $\mathrm{Na}_{2} \mathrm{CO}_{3}$ 
extraction procedures. J. Plant Nutr. Soil Sci. 170, 522-529.
Zeraatpishe, M., Khormali, F. 2012. Carbon stock and mineral factors controlling soil organic carbon in a climatic gradient, Golestan province. J. Soil Sci. Plant Nutr. 12 (4), 637-654. 